\title{
Facilitating the Teaching of English through the Teaching of Arts
}

\author{
Abdul Muth'im \\ Lambung Mangkurat University \\ Banjarmasin, Indonesia \\ muthimabdul@gmail.com
}

\begin{abstract}
Art seems to be one of the fields that make the person involving in the field highly motivated, full-heartedly obsessed, and free to explore, to exploit, to express as well as to experiment with what he/she is engaging in. It might be these characteristics that enable an artist to produce a piece of artwork which is free of the imposition of external factor(s). It might be these situations, too, that become the fundamental reason why one does the job with full of enjoyment. In turn, it might be this joyful condition that triggers and encourages the art worker(s) to willingly and enthusiastically initiate, proceed, and accomplish their work. The characteristics shown by the artists in work and their spirits in doing the job could be adopted and made use of in the teaching and learning English. If we want the teaching and learning English in our country successful, the feeling of joy and the spirit are two conditions needed in the teaching and learning the language. This paper tries to explore and exploit the possibility of using art as an alternative strategy in the teaching and learning English for high school students.
\end{abstract}

Keywords — teaching; learning; language; English

\section{INTRODUCTION}

The idea of teaching language in general and especially in teaching English through different subject matters and various programs is not new. It has long been practiced among language teachers around the world for decades. Different names are used for such kind of teaching program. For example, as mentioned by Sadtono, in the United States the program is called Languages Across Curriculum (LAC), in Australia it is called Language for Understanding Across the Curriculum (LUAC), and in Europe and some other countries it is called Content and Language Integrated Learning (CLIL), whereas in Indonesia it is called English Across the Curriculum (EAC) [1].

To implementation of this program, various responses were given. Some were pessimistic, some were optimistic about conditions, and some others were fully optimistic. Sadtono from Ma Chung University, Malang, for instance is one of the experts who is doubtful about the efficacy of the program. He analogizes the teaching of EAC as an uphill battle. For him, to get success in the teaching of EAC, two ideal major components: the teachers' English proficiency and the students' English proficiency should match. If the ideal situation is not possible, the English of the teachers would be awfully difficult [1].

For Agustien from State University of Semarang (UNES) who worked for SEAMEO-RELC, Singapore, the success of
EAC in Indonesian schools is still a dream. She argued, "when the academic curriculum is encoded and conveyed in a language rather than what the pupils use in the community, the challenge is greater". She concluded that the challenges of EAC in Indonesian context cover the following: (1) for many, Indonesian language is a second language in the sense that Indonesian is not their mother tongue, so that when entering schools, the students are expected to develop their communicative competence in Indonesian to the level that enables them to participate in the community they live in and to pass the national exam, (2) on top of developing Indonesian as their second language, students are expected to learn English as the language of schooling, and (3) although the introduction of English is meant for developing communicative competence, people who send their children to English speaking schools also expect that their children will learn the curriculum content to a level that enables high school graduates to enter English speaking universities abroad [2].

Two teachers from SMP Santa Agnes Surabaya perceived EAC optimistically. For them, EAC is beneficial for students. They argued that the teaching of EAC could result in good success in students' learning. This was proven by the result of their experiment. They claimed: "To our experiences in classes 7 and 8, Science and Mathematics results which are held in English have improved significantly and only $12.5 \%$ failed (5 of 40 pupils) compared to $30 \%$ (12 of 40 pupils) when held in Bahasa Indonesia" [3]. In addition, EAC is not only beneficial for students but it is also advantageous for the teachers. In answering her research question on how the science teachers used the language in the classroom when presenting the concepts of science in English, Rakhmawati, who conducted a research on the language use of science teachers in presenting science using English at Godwins Elementary School in Surabaya discovered that the science teachers showed a good performance in presenting the science concepts [4].

With the above pictures in my mind, I write this paper. The purpose of this paper is that the teaching of English may be carried out and can be facilitated through the teaching of arts.

\section{METHODS}

This paper is partly based on the revelation of the results of some research on the field, is partly based on our talk with a vice principal of a public elementary school in Chiangmai, Thailand, when we had a job travel to monitor our students practicing teaching in Thailand some time ago, and is partly based on the contemplation I did concerning my job as an 
English teacher. In our talk, she was asking whether it is possible for Lambung Mangkurat University to send music teachers and well as sports teachers who could teach music and sport using English for Thai elementary school students. The other inspiration comes from the fact that the teaching and learning of EAC in some schools in Indonesia indicate some degree of "success". Why can the teaching and learning English in Indonesia not be facilitated through the teaching of arts?

\section{RESULT AND DISCUSSION}

What can be learned from arts education? According to [5], the arts (1) teach children to make good judgment about qualitative relationship, (2) teach children that problems can have more than one solution and that questions can have more than answer, (3) celebrate multiple perspectives, (4) teach children that in complex forms of problem solving purposes are seldom fixed, but change with the circumstance and opportunity, (5) make vivid the fact that neither words in their literal form nor numbers exhaust what we can know, (6) teach students that small differences can have large effects, (7) teach students to think through and within a material, (8) help children learn to say what cannot be said, (9) enable us to have experience we can have no other source and through such experience discover the range and variety of what we are capable of feeling, and (10) in the school curriculum symbolizes to the young what adults believe is important [5].

Calouste Gulbenkian Foundation, as cited by [6] listed some contribution contributed by arts education. They are: (a) it develops the full variety of human intelligence, (b) it develops the ability for creative thought and action, (c) it educates feeling and sensibility, (d) it explores values, (e) it enhances understanding of cultural changes and differences, and (f) it develops physical and perceptual skills.

The results of some research on the characteristics of arts education have already indicated their efficacies. For instance, NEA ARTS reported that recent research conducted by [7] found that we were not just learning dance, music, theater, and visual arts-he discovered that students with access to inschool arts instruction performed better academically, participated more actively in extra-curricular activities, and were more likely to pursue higher education. This is in line with the result of a study conducted by Winner and Hetland as quoted by [8] which found that "students are actively involved and excited about learning, and teachers and students alike enjoy coming to school. The arts create a positive and inviting learning environment - resulting in higher attendance rates and fewer dropout rates". Eisner added, while the teacher of spelling is not particularly interested in the ingenuity of response from students, the art teacher seeks it. Besides, the arts celebrate multiple conceptions of virtue. Furthermore, they teach that there are many ways to see and interpret the world and that people can look through more than one window.

There are some types of arts through which English teaching and learning can be carried out. [9] suggests that arts education can be applied to different names or bases. They are arts-based, arts-infused, arts included, arts expanded, arts professional, and arts extras.
In arts-based, the arts supply the content for what is learned, serve as a model for teaching, learning, and assessment, and provide a window through which non-arts subjects are explored. In arts-infused, the arts are infused into the curriculum, artists or works or arts are brought from outside in to enrich whatever is going on in arts and non-arts classes or activities. In arts included, the arts are situated among students' required courses and are taught, respected, and allotted time with the same regard as non-arts courses. In arts expanded, education in the arts takes students outside of school into the larger community. In arts professional, the impression of professional arts educational opportunities abound is given. In arts extras, arts as nonacademic extras are reserved for inschool space and time outside of the daily curriculum.

\section{A. Teaching English through drama}

Drama, in accordance with [10], is the act of using the imagination to become someone or something other than oneself. For [11], the drama is a composition in verse or prose intended to portray life or character or to tell a story usually involving conflicts and emotions through action and dialogue and typically designed for theatrical performance (MerriamWebster, as quoted by [11]. Of course, in ESL/EFL context teaching English through drama is not meant teaching acting and performance skills. Instead, its objective is to teach core curricular areas using drama.

What is the use of drama in the teaching and learning language? Maley, as cited by [12], listed some points which support the use of drama in a language classroom. They are: (1) it integrates language skills in a natural way, (2) it integrates verbal and non verbal aspects of communication, thus it brings together both mind and body, and restores the balance between physical and intellectual aspects of learning, (3) it draws upon both cognitive and affective domains, thus restores the importance of feeling as well as thinking, (4) by fully contextualizing the language, it brings the classroom interaction to life through an intensive focus on meaning, (5) the emphasis on whole-person learning and multi-sensory inputs helps learners to capitalize on their strength and to extend their range. In doing so, it offers unequalled opportunities for catering to learner differences, (6) it fosters self-awareness (and awareness of others), self-esteem and confidence; and through this, motivation is developed, (7) motivation is likewise fostered and sustained through the variety and sense of expectancy is generated by the activities, (8) there is a transfer of responsibility for learning from teacher to learners which is where it belongs, (9) it encourages an open, exploratory style of learning where creativity and the imagination are given scope to develop. This, in turn, promotes risk-taking, which is an essential element in effective language learning, (10) it has a positive effect on classroom dynamics and atmosphere, thus facilitating the formation of a bonded group, which learns together, (11) t is an enjoyable experience, (12) it is low-resource. For most of the time, all you need is a 'roomful of human beings' [12].

According to [13], drama or dramatic activities can be used in ELT to: (a) integrate concepts, skills and ideas from various subject areas, including social students, mathematics, science, and literacy, (b) gain an understanding of real world events 
from the past and the present, the individuals who shaped these shaped these events, and the individuals who may influence them in future, (c) develop reading comprehension skills by entering the world of a text through role playing, interacting with others, visualizing events, concepts, and information, and dramatizing the experiences of fictional characters and real-life individuals, (d) produce written works in a variety of contexts for different audiences that demonstrate increasing technical skill, self-defense, and effective management of multimodal and electronic texts, (e) discover and scrutinize ethical aspects of social issues such as equity, social justice, citizenship, civil rights, bigotry, bullying, and other forms of antisocial behavior and their reversals from various points of view, (f) generate and use spoken, written, visual, and multimodal texts that demonstrate increasing fluency in the way of vivid description, sensory details, and effective persuasive and self-reflective writing, (g) understand and develop compassion for others' representations of ideas, values, beliefs, experiences, and life conditions - from literary characters and challenged individuals to historical figures, (h) acquire critical thinking skills in terms of examining, questioning, and perhaps challenging social practices and the language, actions, and beliefs that drive these practices, and investigating and evaluating texts concerning their manner of representing certain people, groups, and notions of reality, (i) gain social skills through group problem solving, listening to differing views, respecting, weighing, and perhaps acting on another's proposals, and expressing empathy and compassion, and (j) develop appreciation for the art of drama and theater [13].

What drama activities that can be used in the teaching and learning a language. Concerning this, [12] proposes the following: mime, role-play, simulation, and improvisation.

Mime, in accordance with [14], is defined as "a non-verbal representation of an idea or story through gesture, bodily movement and expression" [14] It helps develop students' power of imagination and observation and can also be quite simply "a source of great enjoyment" with students tending "to be very enthusiastic about this aspect of drama [15]. Savignon claims that the mime helps learners become comfortable with the idea of performing in front of peers without concern for language and that although no language is used during a time it can be a spur to use language [16]. Rose argues that it is a great way of reinforcing memory by means of visual association, and recall of language items is assisted whenever an associated image is presented. Ur argues that mime can generate language use where the explanation is required-teachers' instruction and the discussion of the students - if the mime involves pair work or group work, learners normally find it easier and more motivating when they have to accomplish a task [17].

Livingstone claims that role play can also help recreate the language students used in a different situation, the sort of language students are likely to need outside the classroom [18]. Venugopal argues that role-play involves being an imaginary person usually in a hypothetical situation and sometimes in a real one [18]. Richards claims that role-play involves a situation in which a setting, participants and a goal problem are described [19].
Jones calls a simulation as a case study where learners become participants in an event and shape the course of the event [20] Jones defined simulation as "a reality of functions in a simulated and structured environment [21]. The function of simulation in accordance with Smith is to give participants the opportunity to practice taking on specific roles and improvising within specific situations on the assumption that with practice the participants will play their roles more effectively when situations involving similar skills occur in real life. A simulation activity provides specific situation within which students can practice various communication skills like asserting oneself, expressing opinions, convincing others, arguing eliciting opinions, group-problem solving, analyzing situations and so on [22].

Improvisation, in accordance with Landy, is defined as an unscripted, unrehearsed, spontaneous set of action in response to minimal directions from a teacher, usually including statements of whom one is, where one is and what one is doing there. The focus is thus on identifying with characters, enacting roles and entering into their inner experience of imagination and fantasy [23]. For Hodgson and Richards, improvisation is defined as a spontaneous response to the unfolding of the unexpected situation [24]. McCaslin argued that the focus of improvisation is on helping learners to discover their own resources from which their most imaginative ideas and strongest feelings flow, participants gain freedom as selfdiscipline and the ability to work with others develops [25]. In implementing improvisation, [12] reminds us that before the improvisation is begun the teacher or the instructor has to involve the establishment of a context which serves to inform the participants where they are and what they are expected to portray in their inter-relationships with other characters. Since this is an unscripted, unrehearsed drama exercise, the participants are at liberty to make their spontaneous contribution as the play unfold [12].

\section{B. Teaching English through music}

It is believed that music is a language that can be enjoyed by anyone anytime anywhere. In other words, it is a universal "language" of human beings. According to Bridgewater, music provides opportunities to promote: (1) spiritual development through developing pupil's awareness of the power of music to take the listener out of the commonplace and helping pupils use music to express and reflect on their own thoughts and feelings; (2) moral development through helping pupils exercise responsibility in the choices and decisions they and others make as part of the creative process, valuing their own and others' work and recognizing the effect of music; (3) social development through helping pupils share music-making and develop a sense of social cohesion, recognizing the value of different contributions and their own responsibility to support and enrich the work of others, and recognizing the need for different roles in group performance; (4) cultural development through helping pupils recognize how music influences and reflects the way people think and feel, relating music to the time and place in which it was created and performed, and through analyzing, evaluating and reflecting on music from contrasting and identifying how and why some aspects change or stay the same [26]. 
Ref [27] found that music education equips students with the fundamental abilities to learn, to achieve in other core academic subjects, and to develop the capacities, skills, and knowledge essential for lifelong success.

Music education prepares students to learn in enhancing fine motor skills, preparing the brain for achievement, fostering superior working memory, and cultivating better-thinking skills. It also facilitates student academic achievement in improving recall and retention of verbal information, advancing math achievement, boosting reading and English language arts (ELA), and improving average SAT score. Music education develops the creative capacities for lifelong success, too, in sharpening student attentiveness, strengthening perseverance, equipping students to be creative, and supporting better study habits and self-esteem.

In addition, Bridgewater claims that music provides opportunities for pupils to develop the key skills of communication through presenting music to different audiences and discussing and sharing ideas with others; application of numbers through recognizing pattern, sequence, order and rhythmic relationships; ICT through using a range of ICT to compose and perform music; working with others through taking different roles and recognizing and supporting the different contributions of others in groups and ensemble work; improving own learning and performance through appraising their own work, recognizing the need for perseverance, developing the ability to use time effectively, and increasing their ability to work independently; problem solving through achieving intentions when composing and presenting performances to different audiences and in different venues [26] .

In term of the contribution of music in English teaching and learning, [26] claims that music encourages children to listen carefully for specific purposes and to articulate responses. The singing song develops children's language skills by focusing attention on rhythm, rhyme, diction, and meaning. By working with others in a musical setting, children develop their ability to communicate ideas effectively.

\section{Teaching English through dance}

Dance, in accordance with McGreevy-Nichols and Scheff, [28] is a movement created and executed to satisfy a need. It can be stylized, done to music or not, tell a story or not, create images, use space, define moods, create and channel energy. Cone and Cone claim that dance provides children with means to express and communicate what they really feel and know about themselves and the world [28]. [29] added that utilizing dance as part a more holistic approach to teaching can create increased motivation and engagement for students. Awareness and use of the findings imply that teachers can be successful in supporting student learning [29].

\section{CONCLUSION}

From the discussion so far, it is apparent then that arts education may facilitate and may bring about the benefits for education in general and especially for the teaching and learning English. I agree with what Eisner suggests that problems of education can have more than one solution and that questions concerning education can have more than an answer. There are multiple perspectives. Problem-solving purposes are seldom fixed, but change with the circumstance and opportunity, and the fact that neither words in their literal form nor numbers exhaust what we can know.

\section{REFERENCES}

[1] Sadtono, E. 2010. English Across the Curriculum: An Uphill Battle. Paper presented at "The National Conference on English Across Curriculum". Hosted by Widya Mandala Catholic University, Surabaya, 4 - 5 May 2010.

[2] Agustien, Helena I.R. 2010. English across the Curriculum in Indonesian Schools: Dreams, Challenges, and Reality. Paper presented at "The National Conference on English Across Curriculum". Hosted by Widya Mandala Catholic University, Surabaya, 4 - 5 May 2010.

[3] Situmorang, Mangaris \& Tjandrarini, Maria Pretty. 2010. Struggles in Teaching Science and Mathematics in English. Paper presented at "The National Conference on English Across Curriculum". Hosted by Widya Mandala Catholic University, Surabaya, 4 - 5 May 2010.

[4] Rakhmawati, Ivonny. 2010. The Language Use of Science Teachers in Presenting Science Using English at Godwins Elementary School. Paper presented at "The National Conference on English Across Curriculum". Hosted by Widya Mandala Catholic University, Surabaya, 4 - 5 May 2010.

[5] Eisner, Elliot W. 2003. What do the Arts Teach? In JAE I.ICWTAEI

[6] Boyd, Janis. 2000. Myths, Misconceptions, Problems, and Problems in Arts Education.

[7] Catterall, James. 2013. Engaged and Empowered The Importance of Arts Education. NEA ARTS Number 1, 2013.

[8] Rushlow, Bonnie B. 2007. Why Middle School Art Matters. NAESP Vol. 16 , No. 2

[9] Davis, Jessica Hoffmann. 2008. Why Our Schools Need the Arts. New York: Teachers College Press.

[10] Moore, Mandie M. 2004. Using Drama as an Effective Method to Teach Elementary Students. The Honors College at Digital Commons@EMU.

[11] Hu, Yue (Vicky). 2011. Using Drama for ESL Teaching. A Seminar Paper Research Presented to the Graduate Faculty University of WisconsinPlatteville.

[12]Zyoud, Munther. n.d. Using Drama Activities and Techniques to Foster Teaching English as a Foreign Language: a Theoretical Perspective. Al Quds Open University.

[13] Dowdy, Joanne Kilgour \& Kapan, Sarah (eds). 2011. Teaching Drama in the Classroom. Rotterdam/Boston/Taipei: Sense Publishers.

[14] Dougill, John. 1987. Drama activities for Language Learner. London: McMillan Publishers.

[15] Hayes, Suanne Karbowska. 1984. Drama as a second language: A practical Handbook for language teachers. National Extension College.

[16] Savignon, S. 1983. Communicative Competence. London: AddisonWesley.

[17] Ur, Penny. 1981. Discussions that work. Cambridge: Cambridge University Press.

[18] Livingstone, C. 1983. Role Play in Language Learning. London: Longman.

[19] Richards, Jack. 1985. Conversational competence through role play. RELC Journal, 16:1.

[20] Jones, K. 1980. Simulations: A Handbook for teachers. London: Kegan Paul Ltd.

[21] Jones, K. 1982. Simulations in Language Teaching. Cambridge: Cambridge University Press. 
[22] Smith, S.M. 1984. The Theater Arts and the teaching of second language reading. Massachusetts: Addison Wesley.

[23] Landy, R.S. 1982. Handbook of Educational drama and theater. London: Greenwood Press.

[24] Hodgson, J. \& Richards, E. 1974. Improvisation. London: Eyre Methuen.

[25] McCaslin, N. 1980. Creative Drama in the Classroom. Studio City: Players press.

[26] Bridgewater. 2014. Music Policy.

[27] Arts Education Partnership. 2011. Music Matters.

[28] Crowe, Susan M. 2006. Dance, Drama, and Music - a Foundation for Education: A Study on Implementing the Performing Arts in the Early Years of Education. School of Education RMIT University.

[29] Fegley, Laura Elizabeth. 2010. The Impact of Dance on Student Learning: Within the Classroom and Across the Curriculum. A Project Submitted to the Faculty of the Evergreen State College. 